\title{
Atrazine Degradation Pathway and Genes of Arthrobacter sp. FM326
}

\author{
Ming-Rui Li, Fang-Dong Zhan, Jian-Jun Chen, Yan-Qun Zu, Yuan Li* \\ College of Resources and Environment, Yunnan Agricultural University, Kunming, China
}

Received: 10 October 2019

Accepted: 15 December 2019

\begin{abstract}
The objective of this study was to examine the atrazine biodegradation pathway and its genes of the bacteria Arthrobacter FM326, and to understand the degradation mechanism. Our laboratory has found that Arthrobacter FM326 is a highly efficient atrazine-degrading bacteria. A suspension of FM326 was grown in an inorganic salt medium containing atrazine, and during cultivation the content of atrazine and its degradation products were determined every $24 \mathrm{~h}$ to reveal the FM326 atrazine degradation pathway. The results revealed the expression of the degradation genes trzN, atzB and atzC during cultivation and that the atrazine content of the medium was decreased in the presence of FM326 when compared to the control group. During cultivation of FM326, hydroxyl atrazine levels increased at first then stabilized during the training process, before declining at $120 \mathrm{~h}$. The cyanuric acid content increased at first and then decreased, and was significantly reduced in FM326 when compared to the control, while the ammonia nitrogen content increased gradually and was significantly increased when compared to the control. There was no significant change in the pH of the FM326 and control cultures. FM326, which expresses atrazine-degrading genes, could completely degrade atrazine into $\mathrm{CO}_{2}$ and $\mathrm{NH}_{3}$ and did not accumulate cyanuric acid in culture.
\end{abstract}

Keywords: degrading strain, atrazine, biodegradation, degrading pathway, mechanism

\section{Introduction}

Atrazine is a triazine herbicide selectively used on maize, sorghum, cotton and other crops [1]. It is stable and persistent in soil, which has brought huge pollution to soil, surface water and groundwater [2]. In addition, atrazine is a hormone disruptor, harmful to human health and the sustainable development of the ecosystem [3-4]. At present, the way to deal with pesticide pollution is to control the quantity of pesticides in the

*e-mail: yuanliynau@163.com environment, including landfill treatment of polluted soil (which is also expensive). Microbial remediation is a good alternative method that has high efficiency and leaves no residue [5-7].

Atrazine can be deaminated, dechlorinated, and ring cracked by microorganisms. To date, many atrazinedegrading microbes have been found [8-18], and some highly efficient atrazine-degrading strains have been constructed by genetic engineering [19]. Among those, the degradation pathways of the Pseudomonas sp. ADP and Arthrobacter aurescens TC1 strains have been most extensively studied, and they are used as the model strains for the study of atrazine biodegradation [20-22]. The degradation genes atzA, B, C, D, E, and F, 
in Pseudomonas sp. ADP strain encode the six enzymes AtzA, B, C, D, E, and F, respectively. Under the action of these six enzymes, atrazine was completely mineralized [22]. Another atrazine degradation pathway is found in Arthrobacter sp. with the genes atzA, B, and $\mathrm{C}$ [23], or trzN-atzB, and $\mathrm{C}[21,24]$, which encode the degrading enzymes AtzA, B, and C, or TrzN-AtzB, and $\mathrm{C}$, respectively. Although atrazine can be degraded into cyanuric acid without further degradation, the gene atzD was amplified on the chromosome of Arthrobacter sp. MCM B-436, which encodes the AtzD - an enzyme that can open the triazobenzene ring of cyanuric acid and degrade atrazine completely [25].

The degradation pathway and products of atrazine by Pseudomonas sp. ADP have been elucidated. Firstly, the dechlorination reaction is carried out to produce hydroxyapatrazine, after which the ethyl side chain is removed to form $\mathrm{N}$-isopropyl cyanuric acid monoamide, the isopropyl side chain removed to produce cyanuric acid, the triazobenzene ring is opened and biuret is produced and then the N-N bond is broken to form urea or allophanate. Finally, the urea or allophanate is completely degraded into $\mathrm{CO}_{2}$ and $\mathrm{NH}_{3}$. This is the pathway by which most microbial strains degrade atrazine, and while it is a common pathway in Gramnegative bacteria [16], most of these bacteria will only use the first three steps of the pathway, and thus will accumulate cyanuric acid in the medium [26]. In the six steps of the degradation pathway, the formation of hydroxyapatrazine, cyanuric acid, and the cleavage of the triazobenzene ring are the rate-limiting steps.

When considering the biological safety of exotic species, it is necessary to screen atrazine-degrading strains in areas where the environment is contaminated by atrazine. A highly efficient atrazine-degrading strain, FM326, was obtained by enrichment technology in Yunnan Province, where atrazine is widely used and contaminates the environment [17]. The characteristics of atrazine degradation and the identification of basic growth conditions of this strain have been studied. In comparison to the results of previous studies, the degradation characteristics of FM326 are similar to those of other Arthrobacter strains. Atrazine degradation genes are highly conserved, especially atzB, which encodes hydroxyapatrazine deethylaminohydrolase, and atzC, which encodes $\mathrm{N}$-isopropyl cyanuramide isopropylaminohydrolase. The atzB and atzC genes exist in almost all reported atrazine-degrading bacteria. This study examines the degradation pathway of atrazine by FM326 through the analysis of degradation products and genes in order to provide the basic information necessary to assist in the use of the strain to remediate contaminated environments.

\section{Materials and Methods}

\section{Materials, Reagents, and Culture Medium}

The strain used was Arthrobacter sp. FM326, which was identified in an earlier study [17]. Atrazinecontaminated soil samples were collected from the Kunming Pesticide Factory located in Fumin County, Yunnan Province, China. Through enrichment and domestication, soil suspension was coated onto a solid medium (due to its insolubility, atrazine makes culture medium turbid). Colonies that could form a transparent degradation zone were selected and the atrazine degradation ability of these strains was determined. FM326 was identified as a highly efficient degrading strain (the degradation efficiency could reach $97 \%$ after 96 hours in medium containing $1000 \mathrm{mg} / \mathrm{L}$ atrazine).

Pure atrazine (purity 98\%, Shandong Binnong Technology Co., Ltd. Shandong, China) was provided by the Kunming Pesticide Factory and used as a standard to characterize atrazine-degrading bacteria.

Atrazine, hydroxyapatrazine and cyanuric acid standards (purity 99\%, purchased from Sigma Company) were used in HPLC analytical tests.

Basic inorganic salt medium contained $1.79 \mathrm{~g}$ $\mathrm{K}_{2} \mathrm{HPO}_{4}, 0.45 \mathrm{~g} \mathrm{KH}_{2} \mathrm{PO}_{4}, 0.2 \mathrm{~g} \mathrm{MgSO}_{4}, 0.4 \mathrm{~g} \mathrm{NaCl}$, $1000 \mathrm{~mL}$ distilled water, $\mathrm{pH}$ 7.0. Other medium contained $100 \mathrm{mg}$ atrazine (culture solution containing $100 \mathrm{mg} / \mathrm{L}$ atrazine) as the sole nitrogen source. After preparation, the medium was then sterilized at $121^{\circ} \mathrm{C}$ for $30 \mathrm{~min}$.

Table 1. Primers, annealing temperature, and expected amplification fragment size for amplification.

\begin{tabular}{|c|c|c|c|c|}
\hline Gene & Primers & Sequence $\left(5^{\prime} \rightarrow 3^{\prime}\right)$ & Annealing Temperature $\left({ }^{\circ} \mathrm{C}\right)$ & Fragment Size $(\mathrm{kb})$ \\
\hline \multirow{2}{*}{$\operatorname{trzN}$} & $\operatorname{trz} N-\mathrm{F}$ & ATGATCCTGATCCGCGGACTGA & \multirow{2}{*}{54} & \multirow{2}{*}{1.37} \\
\hline & $\operatorname{trz} N-\mathrm{R}$ & CTACAAGTTCTTGGGAATGAGTG & & \\
\hline \multirow{2}{*}{$a t z A$} & $a t z A-\mathrm{F}$ & TTGCGGTGCAGGTTTTTCGATG & \multirow{2}{*}{65} & \multirow{2}{*}{1.50} \\
\hline & atzA-R & TGCAGCAACGGCGTCATTTC & & \\
\hline \multirow{2}{*}{$a t z B$} & $a t z B-\mathrm{F}$ & GGGCACGGTGCTTAATGG & \multirow{2}{*}{53} & \multirow{2}{*}{1.15} \\
\hline & $a t z B-\mathrm{R}$ & TCAGATCGACGGCAAAGAAAT & & \\
\hline \multirow{2}{*}{$a t z C$} & $a t z C-\mathrm{F}$ & TATTGCCCATTGTGGTGACAAC & \multirow{2}{*}{52} & \multirow{2}{*}{1.08} \\
\hline & $a t z C-\mathrm{R}$ & TTGGGATTGTTGGTGACAGAAT & & \\
\hline
\end{tabular}


Taq DNA polymerase and dNTPs were bought from Beijing Zhuangmeng Biological Company.

\section{Cloning of Atrazine-Degrading Genes}

Primers, annealing temperatures, and the size of expected amplified fragments [27] are shown in Table 1.

PCR reaction: $10 \times \mathrm{PCR}$ buffer $\left(\mathrm{Mg}^{2+}\right.$ plus $) 5 \mu \mathrm{L}$, dNTP mix $(2.5 \mathrm{mM}) 4 \mu \mathrm{L}, 27 \mathrm{f}(20 \mathrm{pmol} / \mathrm{L}) 1.25 \mu \mathrm{L}$, 1492r $(20 \mathrm{pmol} / \mathrm{L}) 1.25 \mu \mathrm{L}, \mathrm{r}$ Taq $(5 \mathrm{U} / \mu \mathrm{L}) 0.25 \mu \mathrm{L}$, total DNA of FM326 strain $0.6 \mu \mathrm{L}$, dd $\mathrm{H}_{2} \mathrm{O}$ supplemented to the total reaction volume of $50 \mu \mathrm{L}$.

The PCR amplification protocol was as follows: predenaturation at $95^{\circ} \mathrm{C}$ for $4 \mathrm{~min}$, then 30 amplification reaction cycles at $95^{\circ} \mathrm{C}-1 \mathrm{~min}, 54^{\circ} \mathrm{C}-1 \mathrm{~min}$, and $72^{\circ} \mathrm{C}-2$ min, followed by $72^{\circ} \mathrm{C}$ for $10 \mathrm{~min}$ then kept at $4^{\circ} \mathrm{C}$. The target band (about $1.5 \mathrm{~kb}$ ) was detected on $1 \%$ agarose gel with $3 \mu \mathrm{L}$ amplification product, visualized with GoldviewTM nucleic Acid Stain. The sequences were submitted to the GenBank database, and Blast analysis was performed to identify homologous genes.

\section{Detecting Atrazine and Its Degradation Products}

Inorganic salt liquid medium was prepared and atrazine was added to a concentration of $100 \mathrm{mg} / \mathrm{mL}$. A total of 27 bottles of $100 \mathrm{~mL}$ culture medium were prepared in $250 \mathrm{~mL}$ Erlenmeyer flasks. Medium was inoculated with $1 \mathrm{~mL}$ of bacteria suspension and cultured at $30^{\circ} \mathrm{C}$ with $120 \mathrm{r} / \mathrm{min}$. At $0 \mathrm{~h}, 24 \mathrm{~h}, 48 \mathrm{~h}, 72 \mathrm{~h}, 96 \mathrm{~h}, 120 \mathrm{~h}$ and $144 \mathrm{~h}$, after inoculation, the culture medium was filtered using a $0.22 \mu \mathrm{m}$ organic system membrane, and the filtrate was collected and stored in a refrigerator at $4^{\circ} \mathrm{C}$. All experiments were done in triplicate.

Conditions for Determining Atrazine and Its Degradation Products by High Performance Liquid Chromatography (HPLC)

The composition of the filtrate was determined by HPLC (Agilent 1200 liquid chromatograph, ultravioletvisible detector, column: ${ }^{18} \mathrm{C}$ reversed-phase silica gel column, $10 \mu \mathrm{L}$ injection volume) with atrazine, hydroxyapatrazine and cyanuric acid standards used as controls. $10 \mu \mathrm{L}$ of sample solution was injected into the sample port of the HPLC by microinjector. The retention time and peak area were detected via UV-VIS, then the standard curve was drawn with the concentration of standard solution as abscissa, and the average area of chromatographic peak as ordinate. The contents of atrazine and its degradation products were calculated using the standard curve.

Atrazine determination conditions were as follows: methanol:water $=80: 20$, column temperature $25^{\circ} \mathrm{C}$, wavelength $222 \mathrm{~nm}$, flow rate $1 \mathrm{~mL} / \mathrm{min}$, retention time $2.3 \mathrm{~min}$. Hydroxyatrazine determination conditions were as follows: methanol:water $=80: 20$, column temperature $25^{\circ} \mathrm{C}$, wavelength $243 \mathrm{~nm}$, flow rate $1 \mathrm{~mL} / \mathrm{min}$, retention time $1.7 \mathrm{~min}$. Cyanuric acid determination conditions were: acetonitrile: $0.5 \%$ phosphoric acid $=50: 50$, column temperature $20^{\circ} \mathrm{C}$, wavelength $216 \mathrm{~nm}$, flow rate $1 \mathrm{~mL} / \mathrm{min}$, retention time 3.809-3.862 $\mathrm{min}$.

$$
\begin{aligned}
& \mathrm{pH}, \mathrm{OD}_{600} \text { and Ammonia Nitrogen } \\
& \text { Determination }
\end{aligned}
$$

After calibration, a $\mathrm{pH}$ meter was used to measure and record the $\mathrm{pH}$ of the microbial culture. The $\mathrm{OD}_{600}$ value of culture medium was measured and recorded with inorganic salt medium used as a blank using a UV-visible spectrophotometer (722, Shanghai Jinghua Science and Technology Instrument Co., Ltd.). Ammonia nitrogen content of filtered medium was determined by Nessler's reagent colorimetry.

\section{Data Statistical Analysis}

The test data were analyzed by ANOVA using IBM SPSS 21.0 and multiple comparisons made by the LSD method. $\mathrm{P}<0.05$ was regarded as significant. Origin 9.0 is used to draw graphics.

\section{Results and Analysis}

\section{Cloning and Sequencing of the Atrazine-Degrading} Genes of FM326

The genomic DNA was extracted and the degrading genes were amplified using the described primers with the amplification results shown in Figs 6-1. FM326 has three degrading genes - trzN, atzB, and atzC - but no atzA gene fragment was found in the amplification tests.

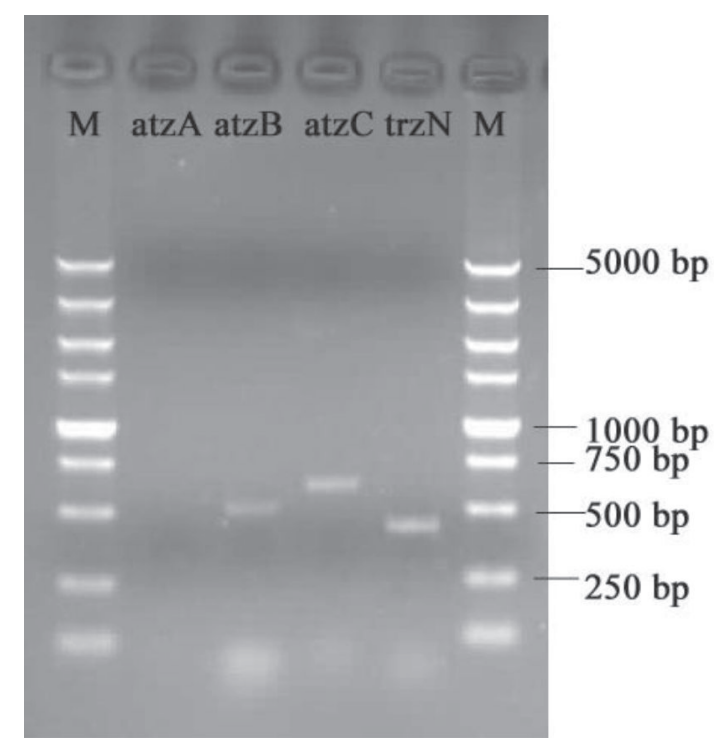

Fig. 1. Agarose gel (1\%) electrophoresis PCR products of atrazine-degrading genes of strain FM326. 
The obtained trzN, atzB, and atzC gene sequences were compared using a basic local alignment search tool (BLAST) online at www.ncbi.nlm.nih.gov. The trzN sequence was $99 \%$ similar to Norcardioides sp.C190 (GeneBank number AF416746.1), Arthrobacter sp.MCM B-436 (AY589015.1), Arthrobacter aurescens TC1 (CP000475.1) and Arthrobacter sp.AD26 (EU091479.1). The atzB sequence was $100 \%$ similar to Pseudomonas nitroreduces (FN568346.1), 99\% to Arthrobacter sp. MCM B-436 (AY589016.1), and 98\% to Pseudomonas sp. ADP (U66917.2). The atzC sequence was 100\% similar to Pseudomonas nitroreducens (FN568347.1), and more than $98 \%$ simila to Arthrobacter sp. MCM B-436 (AY589013.1) and Pseudomonas ADP (U669172). The trzN, atzB and atzC genes of FM326 are homologous to these reported genes, and have comparable genetic relationships.

\section{Levels of Atrazine and Degradation Products during Experimental Period}

\section{Atrazine Levels}

Atrazine levels decreased with culture time (Fig. 2). The reduction of atrazine in the medium containing bacteria is due to a combination of physical, chemical, and microbial degradation, whereas the decrease in medium without bacteria was caused by physical and chemical decomposition.

In the bacterial treatment, atrazine levels decreased rapidly from $0 \mathrm{~h}$ to $24 \mathrm{~h}$, to $12.27 \%$ at $48 \mathrm{~h}$ and finally to $2.50 \%$, whereas atrazine levels in the control decreased rapidly from $0 \mathrm{~h}$ to $24 \mathrm{~h}$, to $64.45 \%$, after which further degradation was slow and showed little extra difference.

\section{Hydroxyatrazine Levels}

Atrazine dechlorination hydrolysis is the first step of microbial degradation of atrazine, and produces hydroxyatrazine. As shown in Fig. 3, hydroxyatrazine was detected in both cultures with levels higher in the

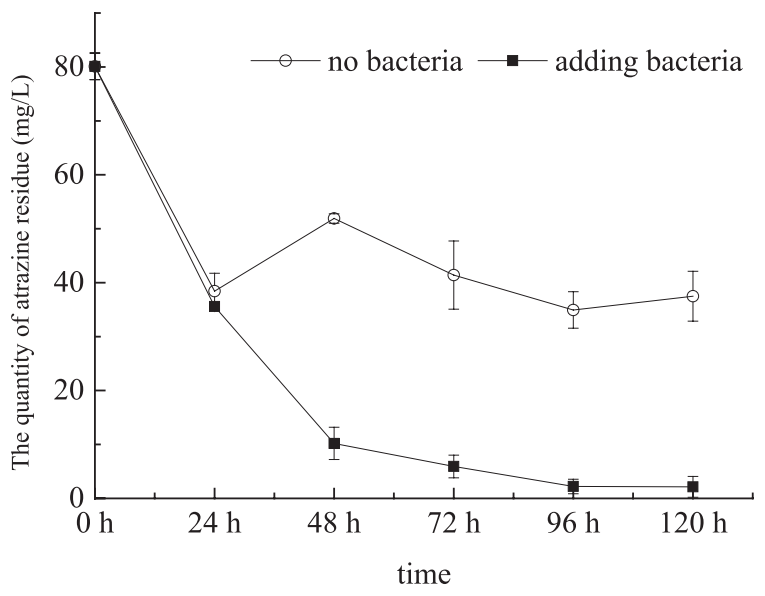

Fig. 2. Change of atrazine residue in the culture.

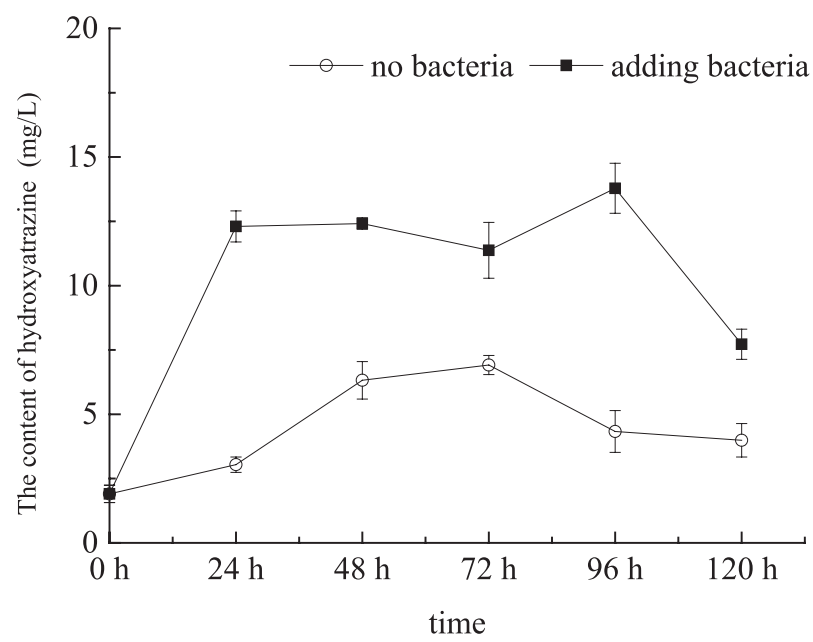

Fig. 3. Change of hydroxyatrazine in the culture.

bacterial culture than the control, except at $0 \mathrm{~h}$, but the differences were not statistically significant.

The hydroxyatrazine levels increased at 24 hours after inoculation, probably because FM326 degradation of atrazine produces a large amount of hydroxyatrazine, after which levels remained basically unchanged from $24 \mathrm{~h}$ to $96 \mathrm{~h}$. At this time point, hydroxyatrazine was being further metabolized to maintain a material balance in the culture medium. Levels began to decrease at $120 \mathrm{~h}$ because there atrazine levels were reduced and the production of hydroxyatrazine was also decreased.

\section{Cyanuric Acid Levels}

The ethyl and isopropyl side chain of hydroxyatrazine were removed by enzymatic catalysis to form cyanuric acid. A large amount of cyanuric acid was detected in the liquid medium of both treatments at $24 \mathrm{~h}$ (Fig. 4). Cyanuric acid levels in the bacterial culture medium decreased gradually over time to $2.05 \mathrm{mg} / \mathrm{L}$. Although the content of cyanuric acid in the control medium also decreased gradually, the change was very small with no further decrease occurring after 72 hours.

Bacteria significantly reduced cyanuric acid levels.

\section{Changes of $\mathrm{NH}_{4}^{+}-\mathrm{N}$ during the Experiment}

Fig. 4 shows that FM326 can degrade cyanuric acid, which is the intermediate product of atrazine degradation; therefore, it is predicted that $\mathrm{NH}_{4}{ }^{+}-\mathrm{N}$ will accumulate in the medium.

As shown in Fig. 5, a small amount of $\mathrm{NH}_{4}{ }^{+}-\mathrm{N}$ can be initially detected in both treatments. $\mathrm{NH}_{4}{ }^{+}-\mathrm{N}$ levels in the bacterial culture increased gradually over time to $3.67 \mathrm{mg} / \mathrm{L}$. $\mathrm{NH}_{4}{ }^{+}-\mathrm{N}$ levels in the control, ranging from $0.4 \mathrm{mg} / \mathrm{L}$ to $0.9 \mathrm{mg} / \mathrm{L}$. From the changes of $\mathrm{NH}_{4}$ ${ }^{+}-\mathrm{N}$ levels, it can be seen that FM326 can completely degrade atrazine with $\mathrm{NH}_{3}$ being one of the final products. 


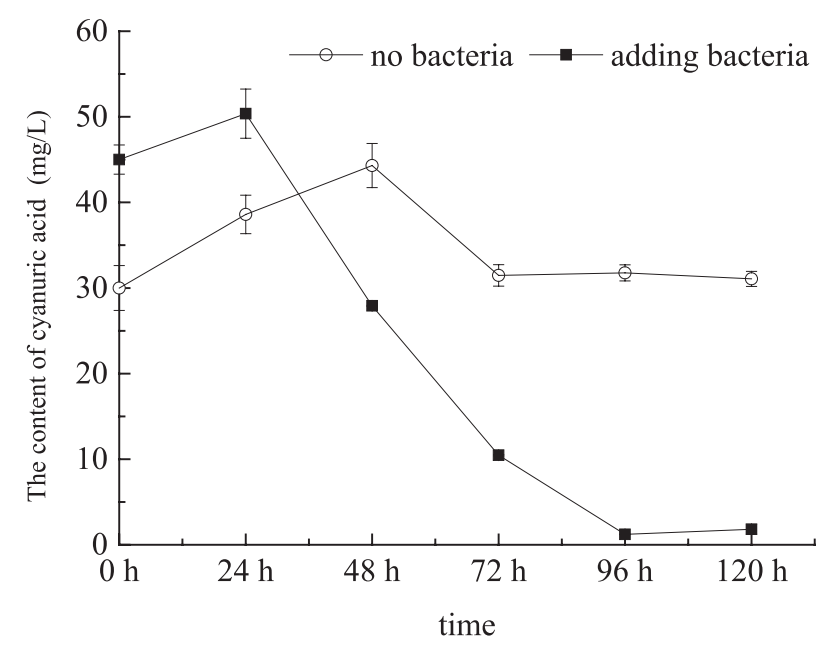

Fig. 4. Change of cyanuric acid in the culture.

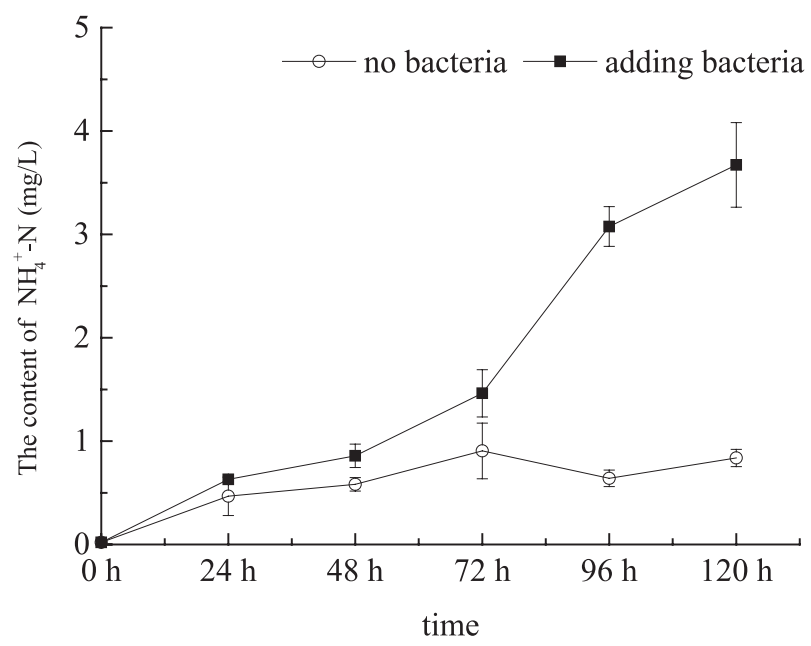

Fig. 5. Change of $\mathrm{NH}_{4}^{+}-\mathrm{N}$ in the culture.

$$
\mathrm{pH} \text { and } \mathrm{OD}_{600} \text { Changes Over Time }
$$

The $\mathrm{pH}$ of the control medium was higher than that with bacteria, but the difference was not significant. In both cases, the $\mathrm{pH}$ decreased first and then increased over time (Fig. 6).

There was no organism growth in the control medium, the turbidity did not change and so the $\mathrm{OD}_{600}$ value remained stable (Fig. 7). The $\mathrm{OD}_{600}$ value increased significantly in the bacterial culture, although a lower value appeared at $72 \mathrm{~h}$, which may be due to experimental errors.

\section{Discussion}

The known genes encoding atrazine degrading enzymes are atzA, atzB, atzC, atzD, atzE, atzF, trzD and trzN. These genes are found in different strains and have their own substrate specificity and are highly conserved. They are generally carried by plasmids,

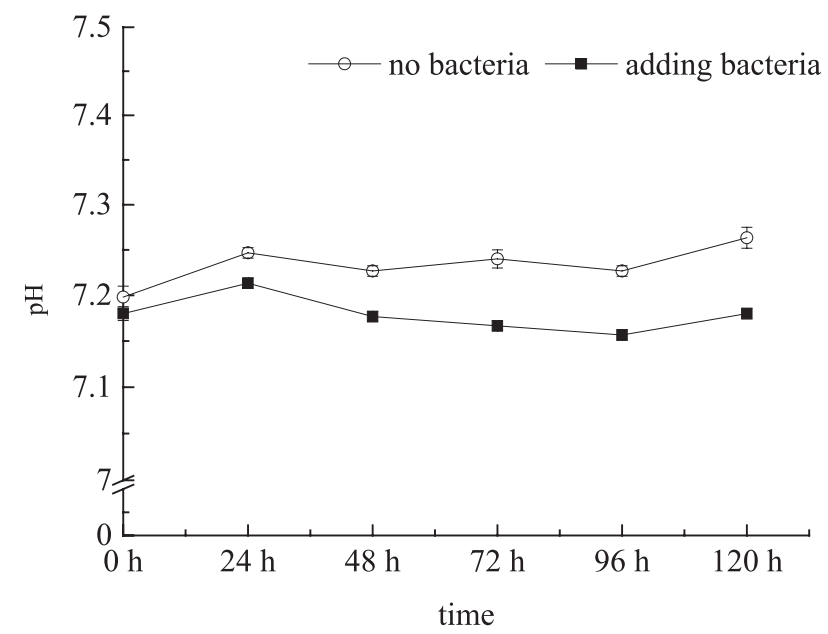

Fig. 6. Change of $\mathrm{pH}$ in the culture.

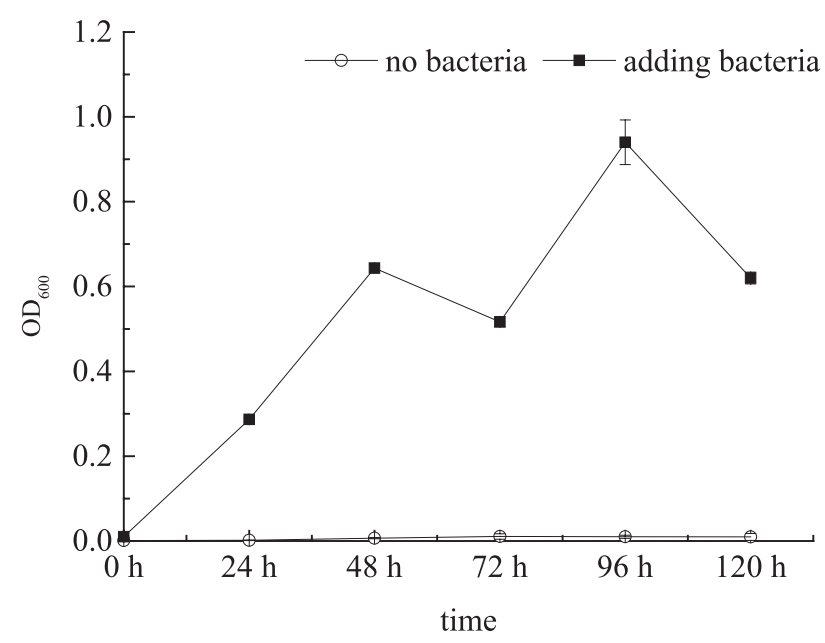

Fig. 7. Change of $\mathrm{OD}_{600}$ in the culture.

which could be widely spread among microorganisms of different genera [28] and therefore there are many microorganisms and microbial communities which may have the ability to degrade atrazine.

Devers et al. [29] studied the genome combinations of 17 strains of degrading bacteria and described three main types: trzN-atzBC, atzABC-trzD and atzABCDEF. Seven of the studied degrading strains had trzN-atzBC genes combinations. It has been reported that this genomic combination could degrade atrazine into cyanuric acid in Arthrobacter aurescens TC1, Nocardioides sp. SP12 and Citricoccus sp. TT3 [22, 30-31]. The combination of atzABC-trzD degrading genome was mainly found in Chelatobacter heintzii, which was found in French soil [32]. The atzABCDEF combination appeared in Pseudomonas sp. ADP [21], Agobterium sp. NEA-D and Ensifer sp. CX-T [24,33]. In addition to the above three genomic combinations, trzN-atzBCDEF was found in Micrococcus luteus sp. $\mathrm{AD} 3$, which can grow with cyanuric acid as the sole nitrogen source and degraded atrazine to $\mathrm{CO}_{2}$ and $\mathrm{NH}_{3}$ 
[34]. In the Arthrobacter strains, the degrading genes were mainly a combination of trz-atzBC genes, for example the 160-kb plasmid of Arthrobacter auresces $\mathrm{TC} 1$ contained trzN, atzB and atzC genes [22, 24], and in Arthrobacter globiformis the trzN and atzC genes were found [13]. DNA sequencing results showed that the nucleotide sequences of the three degrading genes (trzN and atzB and C from FM326) were more than 99\% similar to those of Arthrobacter sp. MCM B-436 [25]. The similarity of the atzB and $\mathrm{C}$ genes compared to Pseudomonas ADP was also more than $99 \%$. This further demonstrates the high conservation and wide prevalence of atrazine-degrading genes.

The pathway of atrazine degradation by Pseudomonas sp. ADP has been studied most thoroughly. Atrazine is degraded by six enzymes to produce hydroxyapatrazine, $\mathrm{N}$-isopropylammelide, cyanuric acid, biuret, urea or allophanate, and finally completely mineralized into $\mathrm{CO}_{2}$ and $\mathrm{NH}_{3}$. Most strains degrade atrazine in this way $[21,35]$. In this study, hydroxyatrazine levels in the medium increased and then stabilized at the end of the experiment. This is consistent with the change of hydroxyatrazine levels seen during atrazine degradation by Arthrobacter sp. MCM B-436. The atzD gene was expressed by Arthrobacter sp. MCM B-436 and it could grow with cyanuric acid, which meant that the strain could completely degrade atrazine [25]. FM326 did not accumulate cyanuric acid in the medium, and an increase in $\mathrm{NH}_{4}{ }^{+}-\mathrm{N}$ levels was detected. This suggests that FM326 can degrade atrazine thoroughly, eventually producing $\mathrm{CO}_{2}$ and $\mathrm{NH}_{3}$, and this study has laid a foundation for future research on the use of FM326 for completely degrading environmental atrazine.

\section{Conclusions}

The gene trzN encodes the first dechlorination hydrolase of the atrazine degradation pathway in FM326 and the genes atzB and atzC encoding the second and third dechlorination enzymes. The nucleotide sequence of these three genes is more than $98 \%$ similar to reported gene sequences, demonstrating the high conservative of the degrading genes. The gene encoding the dechlorination hydrolase in FM326 is trzN rather than atzA, which indicates that the strain has higher degradation efficiency and a wider degradation spectrum, and thus would make for a greater research prospect on atrazine degradation in the future.

According to the levels of atrazine and its degradation products in the culture medium, it was proposed that when FM326 degrades atrazine, the first step was dechlorination hydrolysis to produce hydroxyapatrazine, then the removal of ethyl and isopropyl from hydroxyapatrazine leading to the formation of cyanuric acid. Subsequently, the triazobenzene ring of cyanuric acid was opened, at which point atrazine was completely degraded to form $\mathrm{NH}_{3}$ and $\mathrm{CO}_{2}$.

\section{Acknowledgements}

The authors gratefully acknowledge financial support from the Young and Middle-aged Academic and Technological Leaders Reserve Talents Training Project of Yunnan Province (No. 2018HB043), and the Yunnan Key Research and Development Project (No, 2018BB017, 2019BC001-04).

\section{Conflict of Interest}

The authors declare no conflict of interest.

\section{References}

1. GHOSH P.K., PHILIP L. Environmental significance of atrazine in aqueous systems and its removal by biological processes: an overview. Global Nest Journal, 8 (2), 159, 2006.

2. MONTIEL-LEÓN J.M., DUY S.V., MUNOZ G., BOUCHARD M.F., AMYOT M., SAUVÉ S. Quality survey and spatiotemporal variations of atrazine and desethylatrazine in drinking water in Quebec, Canada. Science of The Total Environment, 671, 578, 2019.

3. BERO L., ANGLEMYER A., VESTERINEN H., KRAUTH, D. The relationship between study sponsorship, risks of bias, and research outcomes in atrazine exposure studies conducted in non-human animals: Systematic review and meta-analysis. Environment international, 92, 597, 2016.

4. JUMHAWANU.,YAMASHITAT.,ISHIDAK.,FUKUSAKI E., BAMBA T. Simultaneous profiling of 17 steroid hormones for the evaluation of endocrine-disrupting chemicals in H295R cells. Bioanalysis, 9 (1), 67, 2017.

5. DOMÍNGUEZ-GARAY A., BOLTES K., ESTEVENÚÑEZ A. Cleaning-up atrazine-polluted soil by using microbial electroremediating cells. Chemosphere, 161, 365, 2016

6. NOUSIAINEN A.O., BJÖRKLÖF K, SAGARKAR S, NIELSEN J.L., KAPLEY A, JØRGENSEN K. S. Bioremediation strategies for removal of residual atrazine in the boreal groundwater zone. Applied microbiology and biotechnology, 99 (23), 10249, 2015.

7. SINGH, S.N., JAUHARI, N. Degradation of atrazine by plants and microbes. In Microbe-Induced Degradation of Pesticides, Singh S.N., Springer, Cham, 213, 2017.

8. FERNÁNDEZ L.A., VALVERDE C., GÓMEZ M.A. Isolation and characterization of atrazine-degrading Arthrobacter sp. strains from Argentine agricultural soils. Annals of Microbiology, 63 (1), 207, 2013.

9. FERNANDES A.F.T., DA SILVA M.B.P., MARTINS V.V., MIRANDA C.E.S., STEHLING E.G. Isolation and characterization of a Pseudomonas aeruginosa from a virgin Brazilian Amazon region with potential to degrade atrazine. Environmental Science and Pollution Research, 21 (24), 1, 2014.

10. SAGARKAR S., BHARDWAJ P., STORCK V., DEVERSLAMRANI M., MARTIN-LAURENT F., KAPLEY A. s-triazine degrading bacterial isolate Arthrobacter sp. AK-YN10, a candidate for bioaugmentation of atrazine contaminated soil. Applied Microbiology and Biotechnology, 100 (2), 903, 2016. 
11. ROUSSEAUX S., HARTMANN A., SOULAS G. Isolation and characterization of new gram-negative and gram-positive atrazine degradation bacteria from different French soils. FEMS Microbiology Ecology, 36 (2), 211, 2001.

12. SWISSAA N., NITZANB Y., LANGZAMB Y., CAHAN R. Atrazine biodegradation by a monoculture of Raoultella planticola isolated from a herbicides wastewater treatment facility. International Biodeterioration \& Biodegradation, 92, 6, 2014.

13. LI Y., LIANG D., SHA J., ZHANG J., GAO J. Isolating and Identifying the Atrazine-Degrading Strain Arthrobacter sp. LY-1 and Applying it for the Bioremediation of AtrazineContaminated Soil. Polish Journal of Environmental Studies, 28 (3), 1267, 2019.

14. BATRA M., PANDEY J., SURI C.R., JAIN R.K. Isolation and characterization of an atrazine-degrading Rhodococcus sp. strain MB-P1 from contaminated soil. Letters in Applied Microbiology, 49 (6), 721, 2009.

15. GAO J., SONG P., WANG G., WANG J., ZHU L., WANG J. Responses of atrazine degradation and native bacterial community in soil to Arthrobacter sp. strain HB-5[J]. Ecotoxicology and Environmental Safety, 159, 317, 2018.

16. SHARMA A., KALYANI P., TRIVEDI V.D., KAPLEY A., PHALE P.S. Nitrogen-dependent induction of atrazine degradation pathway in Pseudomonas sp. strain AKN5. FEMS Microbiology Letters, 366 (1), 2019. https://doi. org/10.1093/femsle/fny277.

17. LI M.R., ZU Y.Q., CHEN J.J., ZHAN F.D., HE Y.M., LI Y. Isolation, Screening and Identification of Atrazinedegrading bacterium FM326 (Arthrobacter sp.). Journal of Agro-Environment Science, 30 (11), 2242, 2011 [In Chinese]

18. JIANG Z., ZHANG X., WANG Z., CAO B., DENG S., BI M., ZHANG Y. Enhanced biodegradation of atrazine by Arthrobacter sp. DNS10 during co-culture with a phosphorus solubilizing bacteria: Enterobacter sp. P1. Ecotoxicology and Environmental Safety, 172, 159, 2019.

19. OFAIM S., ZARECKI R., POROB S., GAT D., LAHAV T., XU X., KASHI Y., ALY R., JIANG J.D., EIZENBERG H., RONEN Z., FREILICH S. Genome-Scale reconstruction of Paenarthrobacter aurescens TC1 metabolic model towards the study of atrazine bioremediation. BioRxiv, 2019. https://doi.org/10.1101/536011

20. ZHAO X., WANG L., MA F., BAI S., YANG J., QI S. Pseudomonas sp. ZXY-1, a newly isolated and highly efficient atrazine-degrading bacterium, and optimization of biodegradation using response surface methodology. Journal of Environmental Sciences, 54, 152, 2017.

21. FERNANDES A.F.T., BRAZ V.S., BAUERMEISTER A., PASCHOAL J.A.R., LOPES N.P., STEHLING E.G. Degradation of atrazine by Pseudomonas sp. and Achromobacter sp. isolated from Brazilian agricultural soil. International Biodeterioration \& Biodegradation, 130, 17, 2018.

22. DEVERS-LAMRANI M., SPOR A., MOUNIER A., MARTIN-LAURENT F. Draft genome sequence of Pseudomonas sp. strain ADP, a bacterial model for studying the degradation of the herbicide atrazine. Genome Announc, 4 (1), e01733, 2016.
23. FLORES A.M., GARNICA A.T., ORDAZ N.R., ALCOCER A.S., RAMÍREZ C.J., CHACÓN D.A., PARADA M.E.M., MAYER J.G. Atrazine biodegradation by a bacterial community immobilized in two types of packed-bed biofilm reactors. World Journal of Microbiology and Biotechnology, 25 (12), 2195, 2009.

24. ZHAO X., MA F., FENG C., BAI S., YANG J.X., WANG L. Complete genome sequence of Arthrobacter sp. ZXY2 associated with effective atrazine degradation and salt adaptation. Journal of Biotechnology, 248, 43, 2017.

25. VAISHAMPAYAN P.A., KANEKAR P.P., DHAKEPHALKAR P.K. Isolation and characterization of Arthrobacter sp. strain MCM B-436, an atrazinedegrading bacterium, from rhizospheric soil. International Biodeterioration \& Biodegradation, 60 (4), 273, 2007.

26. STRONG L.C., ROSENDAH1 C., JOHNSON G., SADOWSKY M.J., WACKETT L.P. Arthrobacter aurescens $\mathrm{TC1}$ metabolizes diverse s-triazine ring compounds. Applied and Environment Microbiology, 68 (12), 5973, 2002.

27. HAN P., HONG Q., HE L.J., YAN Q.X., LI S.P. Isolation, identification and characterization of an atrazinedegrading bacteria ADH-2. Journal of Agro-Environment Science, 28 (2), 406, 2009 [In Chinese]

28. BHARDWAJ P., SHARMA A., SAGARKAR S., KAPLEY A. Mapping atrazine and phenol degradation genes in Pseudomonas sp. EGD-AKN5. Biochemical Engineering Journal, 102, 125, 2015.

29. DEVERS M., AZHARI N.E., KOLIC N.U., MARTINLAURENT F. Detection and organization of atrazinedegrading genetic potential of seventeen bacterial isolates belonging to divergent taxa indicate a recent common origin of their catabolic functions. FEMS Microbiological Letters, 273 (1), 78, 2007.

30. PIUTTI S., SEMON E., LANDRY D., HARTMANN A., DOUSSET S., LICHTFOUSE E., TOPP E., SOULAS G., MARTIN-LAUREN F. Isolation and characterization of Norcardioides sp. SP12, an atrazine-degrading bacterial strain possessing the gene trzN from bulk- and maize rhizosphere soil. FEMS Microbiology Letters, 221 (1), 111, 2003.

31. YANG X., WEI H., ZHU C., GENG B. Biodegradation of atrazine by the novel Citricoccus sp. strain TT3. Ecotoxicology and environmental safety, 147, 144, 2018.

32. ROUSSEAUX S., HARTMANN A., SOULAS G. Isolation and characterization of new gram-negative and gram-positive atrazine degradation bacteria from different French soils. FEMS Microbiology Ecology, 36 (2), 211, 2001.

33. MA L., CHEN S., YUAN J., YANG P., LIU Y., STEWART K. Rapid biodegradation of atrazine by Ensifer sp. strain and its degradation genes. International Biodeterioration \& Biodegradation, 116, 133, 2017.

34. WEN X.S., LI Y., LI J., CAI B.L. Isolation and identification of atrazine-degrading Micrococcus luteus AD3 and studies on its degradation characteristics. Acta Scientiae Circumstantiae, 25 (8): 1066, 2005 [in Chinese]

35. SINGH S., KUMAR V., CHAUHAN A., DATTA S., WANI A. B., SINGH N., SINGH J. Toxicity, degradation and analysis of the herbicide atrazine. Environmental chemistry letters, 16 (1), 211, 2018. 